JISFIM: Journal of Islamic Social Finance Management

Volume 1 Nomor 2 Ed. Juli - Des 2020 : Hal 174 - 191

\title{
Pengaruh Net Profit Margin Dan Rasio Biaya Operasional Pendapatan Operasional Terhadap Kemampuan Zakat
}

\author{
Fitri Purnama Sari Sitompul'1, Fatahuddin Aziz Siregar², Ja'far Nasution3 \\ 1,2,3Institut Agama Islam Negeri Padangsidimpuan \\ JL. H.T. Rizal Nurdin, Km 4,5 Sihitang Kota Padangsidimpuan - Sumatera Utara
}

\begin{abstract}
Abstrak
Zakat merupakan salah satu kegiatan sosial yang diemban PT. Bank Syariah Mandiri dan yang wajid dibayar apabila sudah mencapai nisab. Perhitungan dana zakat yang dikeluarkan 2,5\% dari laba sebelum pajak. Untuk mengetahui kemampuan bank dalam, menghasilkan laba secara relatif menggunakan Net Profit Margin (NPM) dan rasio Biaya Operasinal Pendapatan Operasional berdasarkan data yang diperoleh dari PT. Bank Syariah Mandiri. Penelitian ini dilakukan untuk mengetahui apakah NPM dan BOPO berpengaruh terhadap kemampuan zakat PT. Bank Syariah Mandiri baik secara persial maupun secara simultan. Penelitian ini merupakan penelitian kuantitatif dengan data sekunder dengan teknik analisis data menggunakan metode regresi Linier berganda. Hasil penelitian secara parsial (uji t) menyatakan bahwa, NPM tidak berpengaruh terhadap Zakat. Sedangkan, BOPO berpengaruh terhadap zakat. NPM dan BOPO bersama-sama memiliki pengaruh terhadap zakat.
\end{abstract}

Kata Kunci: Net Profit Margin (NPM), dan rasio Biaya Operasional Pendapatan Operasional (BOPO) Terhadap Zakat.

\begin{abstract}
Zakah is one of the social activities carried out by PT. Bank Syariah Mandiri and those who are required to be paid when they reach the nisab. The calculation of zakah funds issued is $2.5 \%$ of profit before tax. To find out the ability of a bank to generate relative profits using Net Profit Margin (NPM) and the ratio of Operating Costs to Operating Income based on data obtained from PT. Bank Syariah Mandiri. This research was conducted to determine whether NPM and BOPO affect the zakat ability of PT. Bank Syariah Mandiri both partially and simultaneously. This research is a quantitative study with secondary data with data analysis techniques using multiple linear regression methods. The results of the research partially (t test) state that, NPM has no effect on Zakah. Meanwhile, BOPO has an effect on zakah. NPM and BOPO together have an influence on zakah.
\end{abstract}

Keywords: Net Profit Margin (NPM), and the ratio of Operating Costs to Operational Income (BOPO) Against Zakah. 
175 I Pengaruh Net Profit Margin dan Rasio Biaya Operasional Pendapatan Operasional Terhadap Kemampuan Zakat

\section{PENDAHULUAN}

Perkembangan bisnis bank di Indonesia ditandai dengan jumlah bank yang semakin banyak. Bagi suatu negara, bank dapat dikatakan sebagai darahnya perekonomian suatu negara. Dengan kata lain, kemajuan suatu bank di suatu negara dapat pula dijadikan sebagai ukuran negara yang bersangkutan. Semakin maju suatu negara, maka semakin besar peranan perbankan dalam mengendalikan negara tersebut. Artinya keberadaan dunia perbankan semakin dibutuhkan pemerintah dan masyarakatnya (Kasmir : 2008). Bank dijadikan sebagai tempat untuk melakukan berbagai transaksi yang berhubungan dengan keuangan seperti tempat pengamanan uang, melakukan investasi, pengiriman uang, melakukan pembayaran serta melakukan penagihan, oleh karena itu diperlukan berbagai penyesuaian kebijakan di bidang ekonomi termasuk sektor perbankan sehingga diharapkan dapat memperkuat perekonomian nasional.

Di Indonesia sebagai negara muslim terbesar di dunia, telah muncul pula kebutuhan untuk adanya bank yang melakukan kegiatannya berdasarkan Prinsip Syariah (Sjahdeini : 2014). Keinginan ini kemudian tertampung dengan dikeluarkannya Undang-undang No. 7 Tahun 1992 tentang Perbankan sebagaimana telah diubah dengan Undang-undang No. 10 Tahun 1998. Akhirnya pada tanggal 16 Juli 2008 dikeluarkan Undang-undang No. 21 Tahun 2008 tentang Perbankan Syariah, sebagaimana menurut definisi yang disebutkan dalam Pasal 1 Angka 7 Undang-undang tersebut, bank yang menjalankan kegiatan usahanya berdasarkan Prinsip Syariah disebut Bank Syariah.Sehubungan dengan dikeluarkannya Undang-undang tentang Perbankan Syariah, bank-bank syariah pun mulai muncul dan berkembang di Indonesia.

Pada saat banyaknya bank-bank syariah yang muncul dan membuka cabang-cabang di berbagai daerah, salah satunya adalah Bank Syariah Mandiri Tbk. merupakan bank umum syariah yang terbesar di Inłdonesia. Pertumbuhan Bank Syariah Mandiri Tbk. ditandai dengan pertumbuhan asetnya, hal ini dapat di lihat pada tabel berikut:

\section{Tabel 1}

\section{Pertumbuhan Aset Bank Syariah Mandiri Tbk.}

(dalam Persen)

\begin{tabular}{|c|c|c|}
\hline NO & TAHUN & ASET \\
\hline 1 & 2013 & 63,97 \\
\hline 2 & 2014 & 66,96 \\
\hline 3 & 2015 & 70,37 \\
\hline 4 & 2016 & 78,83 \\
\hline
\end{tabular}

JISFIM: Journal of Islamic Social Finance Management, Volume 1, No 2 Tahun 2020 http://jurnal.iain-padangsidimpuan.ac.id/index.php/JISFIM 


\begin{tabular}{|c|c|c|}
\hline 5 & 2017 & 84,67 \\
\hline 6 & 2018 & 88,63 \\
\hline
\end{tabular}

Sumber: www.banksyariahmandiri.co.id.

Berdasarkan tabel 1 di atas dapat dilihat bahwa dari 2013 sampai tahun 2016 pertumbuhan aset PT. Bank Syariah Mandiri Tbk. mengalami kenaikan Aset PT. Bank Syariah Mandiri Tbk. tahun 2013 sebesar 63,97, mengalami peningkatan di tahun 2014,2015 dan 2016 sebesar 66,96, 70,37 dan 78,83 dan tahun 2017 dan 2018 sebesar 84,67 dan 88,63 , dengan sisitem syariahnya PT. Bank Syariah Mandiri Tbk. berhasil menunjukkan kinerja yang baik.

Kinerja suatu perusahaan dapat dilihat dari kondisi keuangan perusahaan tersebut. Kondisi keuangan suatu perusahaan yang bersangkutan, yang terdiri dari laporan keuangan perusahaan yang bersangkutan, yang terjadi dari laporan keuangan perusahaan yang bersangkutan, yang terdiri dari laporan neraca, laporan perhitungan laba serta laporanlaporan keuanganlainnya (Munawir : 2007).

Zakat merupakan salah satu rukun Islam. Kewajiban zakat memiliki hubungan dan keterkaitan yang erat dengan rukun Islam lainnya. Jika sholat merupakan kewajiban badaniyah maka zakat merupakan kewajiban yang dikenakan pada harta kekayaan setiap muslim. Al-Qur'an menyatakan bahwa zakat itu diambil dari setiap harta yang kita miliki, seperti dikemukakan dalam surah at-Taubah: 103 dan juga diambil dari setiap hasil usaha yang baik dan halal, seperti juga digambarkan dalam surah al-Baqarah: 267 (Hafidhuddin : 2002). Begitu juga dengan landasan hukum kewajiban zakat pada perusahaan adalah seperti yang termaktub dalam surah al-Baqarah: 267 dan at-Taubah: 103. Nishab zakat perusahaan sama dengan nishab zakat perdagangan dan sama dengan nishab zakat emas dan perak. Hal ini juga sejalan dengan sebuah hadis riwayat Abu Daud dari Ali bin Abi Thalib bahwa menurut pendapat yang mu'tamar (akurat), 20 misqal itu sama dengan 85 gram emas. Di Indonesia kewajiban zakat perusahaan diatur dalam Undang-undang No. 38 Tahun 1999 tentang Pengelolaan Zakat, dimana bank syariah wajib mengeluarkan zakat yang dijelaskan pada Bab IV pasal 11 ayat (2) bagian (b) dikemukakan bahwa diantara wajib zakat yang wajib dikeluarkan zakatnya adalah perdagangan dan perusahaan. Kemampuan zakat perusahaan dapat dilihat dari hasil laporan keuangan yang bukan hanya sekedar dinyatakan dalam bentuk angka-angka persentase, akan tetapi melalui zakat dapat diketahui bagaimana kinerja suatu perusahaan. Yaitu semakin tinggi zakat yang dikeluarkan oleh perusahaan berarti semakin besar laba yang didapat perusahaan (Muhammad : 2002). Adapun laba yang dimaksud adalah laba sebelum zakat. Penelitian ini 
177 I Pengaruh Net Profit Margin dan Rasio Biaya Operasional Pendapatan Operasional Terhadap Kemampuan Zakat

berkaitan dengan laba bersih, berarti semakin tinggi zakat yang dikeluarkan oleh perusahaan, maka semakin rendah laba bersih yang didapat perusahaan.

Laba adalah keuntungan yang mencerminkan pencapian dari suatu perusahaan dalam hubungan terhadap usaha selama satu periode tertentu (Skousen dkk : 2001). Menurut Frianto Pandia, laba yang besar bukanlah merupakan ukuran bahwa bank telah bekerja secara efesien. Efesien dapat diketahui dengan membandingkan laba yang diperoleh dengan kekayaan atau dengan menghitung profitabilitanya. Rasio profitabilitas adalah rasio untuk mengukur efektifitas bank dalam memperoleh laba (Pandia : 2012). Adapun analisis rasio profitabilitas meneurut Lukman Dendawijaya adalah alat untuk mengukur tingkat efisiensi usaha dan profitabilitas yang dicapai oleh bank yang bersangkutan. Analisis rasio profitabilitas suatau bank antara lain rasio Return On Asset (ROA), rasio Return On Equity (ROE), rasio Return On Equityc (ROA), rasio biaya operasional pendapatan opreasional (BOPO), Net Profit Margin (NPM) (Dendawijaya : 2012). Pada penelitian ini rasio yang digunaka peneliti adaah Net Profit Margin (NPM) dan rasio Biaya Operasional Pendapatan Operasional (BOPO) yaitu rasio yang menggambarkan tingkat keuntungan (laba) yang diperoleh bank dibandingkan dengan pendapatan yang diterima dari kegiatan operasinya. Dalam penelitian ini, NPM dan Rasio BOPO akan megukur kemampuan perusahaan dalam menghasilkan laba bersih serta hubungnya dengan zakat. Berikut data NPM, rasio BOPO Dan Zakat PT. Bank Syariah Mandiri Tbk. Pada tahun 2004-2018 sebagai berikut.

Tabel 2

Rasio NPM, BOPO, dan Zakat PT. Bank Syariah Mandiri Tbk.

Tahun 2004-2018

\begin{tabular}{|c|c|c|c|}
\hline Tahun & $\begin{array}{c}\text { NPM } \\
\text { (dalam persen) }\end{array}$ & $\begin{array}{c}\text { BOPO } \\
\text { (dalam persen) }\end{array}$ & $\begin{array}{c}\text { ZAKAT } \\
\text { (dalam persen ) }\end{array}$ \\
\hline 2004 & 24,81 & 79,51 & 3,21 \\
\hline 2005 & 8,74 & 85,70 & 2,37 \\
\hline 2006 & 6,07 & 83,84 & 2,16 \\
\hline 2007 & 7,82 & 81,34 & 1,97 \\
\hline 2008 & 9,31 & 78,71 & 2,40 \\
\hline 2009 & 11,68 & 73,76 & 2,46 \\
\hline 2010 & 12,14 & 74,97 & 2,50 \\
\hline 2011 & 10,90 & 76,44 & 2,39 \\
\hline
\end{tabular}

JISFIM: Journal of Islamic Social Finance Management, Volume 1, No 2 Tahun 2020 http://jurnal.iain-padangsidimpuan.ac.id/index.php/JISFIM 


\begin{tabular}{|l|l|l|l|}
\hline 2012 & 13,31 & 73,00 & 2,59 \\
\hline 2013 & 9,61 & 84,03 & 2,53 \\
\hline 2014 & 7,26 & 98,46 & 1,98 \\
\hline 2015 & 4,20 & 94,78 & 1,44 \\
\hline 2016 & 4,43 & 94,12 & 1,49 \\
\hline 2017 & 3,23 & 94,44 & 1,54 \\
\hline 2018 & 2,75 & 90,68 & 2,63 \\
\hline
\end{tabular}

Sumber www.ojk.go.id (data diolah)

Dapat dilihat dari tabel di atas perkembangan rasio NPM dan BOPO dan Zakat dari tahun 2004-2018 mengalami fluktuatif. perkembangan NPM mengalami penurunan, dal hal tersebut diikuti BOPO, tahun 2012 dan Zakat tahun 2015. Pada tahun 2004 NPM mengalami kenaikan dan BOPO pada tahun 2014 serta Zakat pada tahun 2004.

Pada penelitian ini telah dijelaskan bahwa terjadi kenaikan BOPO dan NPM yang diikuti dengan penurunan zakat. Seperti NPM pada tahun 2005, 2006, 2007, 2015, BOPO pada tahun 2004,2007,2009,2010,2011, dan Zakat pada tahun 2003, 2007, 2014, 2015, 2016, 2017,. Serta kenaikan NPM pada tahun 2002, 2004, 2010, 2012, 2009 dan BOPO pada tahun 2003, 2005, 2014, 2015, 2016, 2017, 2018, Zakat pada tahun 2002, 2004, 2013, 2012, 2009.

\section{METODE PENELITIAN}

Lokasi penelitian ini dilaksanakan di PT. Bank Syariah Mandiri Tbk. yang dipublikasikan oleh Otoritas Jasa Keuangan (OJK) dengan website www.ojk.go.id, Bank Indonesia dengan website www.bi.go.id, dan PT. Bank Syariah Mandiri Tbk dengan website www.syariahmandiri.co.id. Waktu penelitian dilakukan mulai dari bulan Oktober 2018 hingga selesai.

Metode penelitian merupakan usaha penyelidikan yang sistematis dan terorganisasi (Ruslan : 2004). Maksudnya peneliti melakukan penelitian sesuai dengan aturan dan ketentuan yang berlaku. Penelitian ini menggunakan penelitian jenis kuantitatif. Penelitian dengan pendekatan kuantitatif menekankan analisisnya pada data-data numerical (angka) yang diolah dengan metode statistic (Azwar : 2004).

Sumber data yang digunakan dalam penelitian ini adalah data sekunder. Data sekunder adalah data yang diperoleh dari dokumen-dokumen grafis (tabel, catatan, notulen rapat dan lain-lain) (Arikunto : 2006). Penulis menggunakan data statistik yang diambil dari data statistik Otoritas Jasa Keuangan (OJK) tahun 2004 samapai 2018 yang diambil dari website JISFIM: Journal of Islamic Social Finance Management, Volume 1, No 2 Tahun 2020 http://jurnal.iain-padangsidimpuan.ac.id/index.php/JISFIM 
179| Pengaruh Net Profit Margin dan Rasio Biaya Operasional Pendapatan Operasional Terhadap Kemampuan Zakat

www.ojk.go.id atau dengan website www.bi.co.iddan websitewww.syariahmandiri.co.id. Data yang diperlukan dalam penelitian ini adalah laporan keuangan PT. Bank Syariah Mandiri Tbk. di Indonesia yaitu data pada tahun 2004-2018.

Populasi adalah keseluruhan subjek penelitian. Apabila seseorang ingin meneliti semua elemen yang ada di wilayah penelitian, maka penelitiannya merupakan penelitian populasi. Studi atau Penelitiannya juga disebut studi populasi atau sensus. Adapun populasi dari penelitian ini adalah data yang diperoleh dari Bank Syariah Mandiri mulai tahun 1999 sampai tahun 2017.

Sampel adalah sebagian atau wakil dari populasi yang akan diteliti”. Sampel juga merupakan bagian dari jumlah dan karakteristik yang dimiliki oleh populasi tersebut (Sugiono : 2013). Agar informasi yang diperoleh dari sampel benar-benar mewakili populasi, sampel tersebut harus mewakili karakteristik populasi yang diwakilinya. Untuk memperoleh sampel yang dapat mewakili karakteristik populasi diperlukan metode pemilihan sampel yang tepat. Adapun teknik sampling yang digunakan adalah purposive sampling merupakan teknik penentuan sampel dengan pertimbangan tertentu.

Instrumen pengumpulan data akan mempengaruhi berhasil atau tidaknya suatu penelitian. Instrumen adalah alat yang digunakan untuk pengumpulan data. Oleh karena itu semua alat yang bisa mendukung suatu penelitian untuk mendapatkan hasil berupa data disebut instrumen penelitian. Instrumen yang baik dalam suatu penelitian sangat penting sebab instrumen yang baik dapat menjamin pengambilan data yang akurat.

Untuk memperoleh data-data yang diperlukan dalam penelitian ini, maka peneliti menggunakan dokumentasi sebagai instrumen . Dokumentasi merupakan sumber data yag digunakan untuk melengkapi penelitian baik berupa sumber data yang digunakan untuk melengkapi penelitian baik berupa sumber tulisan, gambar, atau berdasarkan kejadian yang sudah lewat yang semuanya itu dapat memberikan informasi untuk proses penelitian

Teknik analisi data yang digunakan adalah kuantitatif deskriptif penelitian kuntitatif dengan format deskriptif bertujuan untuk menjelaskan, meringkaskan berbagai kondisi, berbagai situasi, atau berbagai variabel yang timbul di masyarakat yang menjadi obyek penelitian itu berdasarkan apa yang trrjadi (Bungin : 2005).

Pengguna statistik deskriptif memiliki tujuan untuk memberikan gambaran atau deskripsi suatu data yang diantaranya dilihat dari rata-rata , minimum, maksimum, dan standar deviasi. Analisis ini mendrkripsikan data sampel yang telah terkumpul tanpa membuat kesimpulan yang bersifat umum. Teknik analisi kuantitatif abanyak dituntut menggunakan angka, mulai dari menggumpulan data, penafsiran dari data tersebut serta penampilan dari http://jurnal.iain-padangsidimpuan.ac.id/index.php/JISFIM 
hasilnya. Demikian juga pemahaman akan kesimpulan penelitian akan lebih baik apabila juaga pemahaman akan kesimpulan penelitian akan lebih baik apabila juga disertai dengan tabel, grafik, bagan atau gambar (Arikunto : 2006).

\section{Uji Analisis Deskriptif}

Analisis deskriptif merupakan metode statistik yang berusaha menjelaskan atau menggambarkan berbagai karakteristik data seperi nilai maksimum dan minimum, rata-rata dan seberapa jauh data-data tersebut bervariasi dan lain-lain (Muhammad : 2002).

\section{Uji Normalitas Data}

Uji normalitas adalah untuk menguji apakah nilai residual yang dihasilkan dari regresi terdistribusi normal atau tidak. Model regresi yang baik adalah yang memiliki nilai residual yang terdistribusi secara normal (Priyanto : 2014). Uji normalitas yang digunakan adalah metode uji One Sample Kolmogrow Smirnov, persyaratan data disebut normal dengan melihat nilai absolute. Jika nilai absolute lebih dari 0,05 , dapat dikatakan bahwa data berdistribusi normal atau probabilitas $\mathrm{p}>0,05$ (Budi : 2006).

\section{Uji Asumsi Klasik}

Sebelum melakukan uji hipotesis, perlu dilakukan pengujian pesyaratan analisis regresi dalam statistik parametrik. Karena dalam penggunaan statistik parametrik, bekerja dengan asumsi bahwa data stiap variabel penelitian yang akan dianalisis harus berbentuk distribusi normal. Regresi yang dilakukan terbebas dari adanya gejala multikolinearitas, heteroskedastisitas dan autokorelasi.

\section{Uji Multikolinearitas}

Multikolinearitas artinya antar variabel independen yang terdapat dalam model regresi memiliki hubungan linear yang sempurna atau mendekati sempurna. Pada model regresi yang baik seharusnya tidak terjadi korelasi yang sempurna diantara variabel bebas. Metode uji multikolinearitas pada penelitian ini yaitu dengan melihat nilai Tolerance dan Variance Inflation Factor ( VIF ) pada model regresi, untuk mengetahui suatu model regresi bebas dari multikolinearitas, yaitu mempunyai nilai VIF (Variance Inflantion Factor) kurang dari 10 dan angka tolerance lebih dari 0,1

\section{Uji Heteroskedastisitas}

Uji Heteroskedastisitas adalah dimana dalam model regresi terjadi ketiksamaan varian dari residual pada satu pengamatan ke pengamatan yang lain. Model regresi yang baik adalah tidak terjadi heteroskedastisitas. Uji heteroskedastisitas dengan cara menggunakan uji glejser dengan cara meregresikan antara variabel independen dengan nilai absolut residualnya. Jika 
nilai signifikansi antara variabel independe dengan absolut residual lebih dari o,o5 maka tidak terjadi masalah heteroskedastisitas.

\section{Uji Autokorelasi}

Uji Autokorelasi digunakan untuk mengetahui ada atau tidaknya penyimpangan asumsi klasik autokorelasi, yaitu korelasi yang terjadi antara residual pada satu pengamatan dengan pengamatan lain pada model regresi. Persyaratan yang harus terpenuhi adalah tidak adanya autokorelasi dalam model regresi. Ukuran dalam menentukan ada tidaknya masalah autokorelasi dengan uji Durbin-Watson (uji D-W) dengan ketentuan nilai DW lebih besar dari 2 lebih kecil dari +2 (Sarwono : 2005).

\section{Analisis Regresi Linier Berganda}

Analisis regresi linier berganda digunakan untuk mengetahui pengaruh atau hubungan secara linier antara dua lebih variabel independen dengan satu variabel dependen. Persamaan regresi linier berganda dengan 2 variabel independen sebagai berikut:

$$
Y^{\prime}=\alpha+\beta_{1} X_{1}+\beta_{2} X_{2} \quad \text { atau } \quad \text { zakat }=\alpha+\beta_{1} N P M+\beta_{2} B O P O
$$

Keterangan:

Zakat : Nilai prediksi variabel dependen (zakat)

a : Konstanta, yaitu Y' jika $\mathrm{X}_{1}$ dan $\mathrm{X}_{2}=\mathrm{O}$

$\beta_{1} \beta_{2} \quad$ : Koefisien regresi linier berganda, yaitu nilai peningkatan

NPM : Net Profit Margin

BOPO : Biaya Operasional Pendapatan Operasional

\section{Uji Koefisien Determinasi $\left(\mathbf{R}^{2}\right)$}

Uji koefisien determinasi $\left(\mathrm{R}^{2}\right)$ pada intinya menunjukkan seberapa jauh kemampuan model dalam menerangkan variabel. Nilai koefisien determinasi adalah antara nol dan satu. Jika $\mathrm{R}^{2}=1$, berarti besarnya persentase sumbangan $\mathrm{X}_{1}$ dan $\mathrm{X}_{2}$ terhadap variasi $\mathrm{Y}$ secara bersama-sama adalah $100 \%$. Jadi seluruh variasi disebabkan oleh $\mathrm{X}_{1}$ dan $\mathrm{X}_{2}$ tidak ada variabel lain yang mempengaruhi Y (Firdaus : 2011).

\section{Uji Koefisien Regresi secara parsial (uji t)}

Uji koefisien parsial dugunakan untuk menguji signifikan atau tidaknya hubungan dua variabel antara variabel independen dengan variabel dependen dengan mengkonstantakan variabel yang tidak diukur (Hasan : 2004), berdasarkan nilai signifikansi jika signifikansi > 0.05 maka $\mathrm{H}_{\mathrm{o}}$ diterima dan jika signifikan < 0,05 maka $\mathrm{H}_{0}$ ditolak.

\section{Uji Koefisien Regresi Secara Simultan (uji F)}

Uji f pada dasarnya menunjukkan apakah semua variabel bebas yang dimaksudkan dalam model mempunyai pengaruh secara bersama-sama terhadap variabel terikat/dependen. 
Kriteria pengujian, jika $\mathrm{F}_{\text {hitung }}>\mathrm{F}_{\text {tabel }}$ maka $\mathrm{H}_{\mathrm{o}}$ ditolak dan $\mathrm{H}_{\mathrm{o}}$ diterima dan jika Fhitung $>$ Ftabel maka Ho ditolak dan Ho ditolak.

\section{HASIL DAN PEMBAHASAN}

Data yang diperoleh peneliti masih berupa data mentah, maka dalam hal ini data diubah ke dalam bentuk Ln (Logaritma Natural) untuk memeudahkan peneliti menguji dan menganalisis data.

\section{Analisis Deskriptif}

Penelitian yang dilakakukan oleh peneliti merupakan penelitian dengan mengolah data sekunder yang diperoleh dari publikasi laporan PT. Bank Syariah Mandiri dari situs resmi Bank Syariah Mandiri yaitu www,ojk.go.id dan www.syariahmandiri.co.id, dari laporan tersebut peneliti menggunakan periode selama 15 tahun. Adapun sampel tersebut yaitu, NPM, BOPO dan Zakat dari tahun 2002 sampai 2016. Untuk memperoleh nilai rata-rata, minimum, maksimum, dan standar deviasi dapat dilihat pada tabel di bawah ini:

\section{Tabel 3}

\section{Hasil Uji Statistik Deskriptif}

Descriptive Statistics

\begin{tabular}{|l|r|r|r|r|r|}
\hline & $\mathrm{N}$ & $\mathrm{m}$ & $\mathrm{m}$ & Mean & Std. Deviation \\
\cline { 2 - 6 } & Statistic & Statistic & Statistic & \multicolumn{1}{c|}{ Error } & Statistic \\
\hline NPM & 30 & 1,56 & 24,81 &, 91683 & 5,02169 \\
BOPO & 30 & 70,11 & 98,46 & 1,53790 & 8,42342 \\
ZAKAT & 30 & 1,36 & 3,21 &, 08085 &, 44284 \\
Valid N & 30 & & & & \\
(listwise) & & & & & \\
\hline
\end{tabular}

Berdasarkan tabel 3 di atas dapat dilihat bahwa untuk variabel NPM jumlah data $(\mathrm{N})$ adalah 30, jumlah minimum 1,56, jumlah maksimum 24,81 sedangkan jumlah rata-rata adalah 91683 dan standar deviasi adalah 5,02169. Untuk variabel BOPO jumlah data (N) Adalah 30, jumlah minimun 70,11, jumlah maksimun 98,46 sedangkan jumlah rata-rata adalah 1,53790 dan standar deviasi adalah 8,42342. Untuk variabel Zakat jumlah data (N) adalah 30, jumlah minimum 1,36. Jumlah maksimum 3,21 sedangkan rata-rata adalah ,o8085 dan standar deviasi adalah, 44284 . 


\section{Uji Normalitas Data}

Uji normalitas yang digunakan adalah metode Uji One Sample Kolmogrow Smirnov dan metode grafik, uji One Sampe Kolmogrow Smirnov digunakan untuk mengetahui distribusi data, apakah mengikuti distribusi normal, poisson, uniform, atau Exponetial. Dalam hal ini untuk mengetahui apakah distribusi residual terdistribusi normal ini menunjukkan hasil uji normalitas variabel NPM, BOPO dan Zakat dengan metode Kolmogorov-Smirnov.

\section{Tabel 4}

Uji Normalitas

\section{One-Sample Kolmogorov-Smirnov Test}

\begin{tabular}{|ll|r|r|r|}
\hline & & NPM & \multicolumn{1}{c|}{ BOPO } & \multicolumn{1}{c|}{ ZAKAT } \\
\hline $\mathrm{N}$ & & 30 & 30 & 30 \\
Normal Parameters ${ }^{\mathrm{a}, \mathrm{b}}$ & Mean & 8,9813 & 83,7493 & 2,2520 \\
& Std. & & & \\
& Deviation & 5,02169 & 8,42342 &, 44284 \\
Most Extreme & Absolute &, 100 &, 131 &, 221 \\
Differences & Positive &, 100 &, 099 &, 130 \\
& Negative &,- 073 &,- 131 &,- 221 \\
Test Statistic & &, 100 &, 131 &, 221 \\
Asymp. Sig. (2-tailed) & &, $200^{\mathrm{c}, \mathrm{d}}$ &, $197^{\mathrm{c}}$ &, $\mathrm{oO}^{\mathrm{c}}$ \\
\hline
\end{tabular}

a. Test distribution is Normal.

b. Calculated from data.

c. Lilliefors Significance Correction.

$\mathrm{d}$. This is a lower bound of the true significance.

Berdasarkan tabel 4 di atas terlihat bahwa nilai absolut dari NPM sebesar 100, BOPO sebesar 099, Zakat sebesar 130 artinya> 0,05 terdistribusi normal dengan menggunakan uji Kolmogrorov-Smirnov.

\section{Uji Asumsi Klasik}

\section{Uji Multikolinearitas}

Multikolinearitas artinya antar variabel independen yang terdapat dalam model regresi memiliki linier yang sempurna ataumendekati sempurna. Model regresi yang baik seharusnya tidak terjadi korelasi di antara variabel bebanya. Untuk mengetahui ada atau tidaknya uji multikolinieritas dengan melihat nilai Variance Inflation Factor (VIF) dan Tolerance, apabila JISFIM: Journal of Islamic Social Finance Management, Volume 1, No 2 Tahun 2020 http://jurnal.iain-padangsidimpuan.ac.id/index.php/JISFIM 
nilai VIF kurang dari 10 dan lebih dari o,1 maka dinyatakan tidak terjadi multikolinieritas. Hasil perhitungan uji multikolinieritas dilihat pada tabel di bawah ini:

\section{Tabel 5}

\section{Uji Multikolinearitas}

\section{Coefficients $^{\mathrm{a}}$}

\begin{tabular}{|c|c|c|c|c|c|c|c|}
\hline \multirow[b]{2}{*}{ Model } & \multicolumn{2}{|c|}{$\begin{array}{l}\text { Unstandardize } \\
\text { d Coefficients }\end{array}$} & $\begin{array}{c}\text { Standardize } \\
\text { d } \\
\text { Coefficients }\end{array}$ & \multirow[b]{2}{*}{$\mathrm{T}$} & \multirow[b]{2}{*}{ Sig. } & \multicolumn{2}{|c|}{$\begin{array}{c}\text { Collinearity } \\
\text { Statistics }\end{array}$} \\
\hline & B & $\begin{array}{l}\text { Std. } \\
\text { Error }\end{array}$ & Beta & & & $\begin{array}{c}\text { Toleran } \\
\text { ce }\end{array}$ & VIF \\
\hline $\begin{array}{ll}1 & \text { (Const } \\
& \text { ant) }\end{array}$ & 3,040 & ,812 & & 3,741 & ,001 & & \\
\hline $\mathrm{NPM}$ & ,049 & ,014 & ,556 & 3,399 & ,002 & ,568 & 1,760 \\
\hline BOPO &,- 015 & ,oo9 &,- 279 & $\begin{array}{r}- \\
1,706\end{array}$ & 100 &, 568 & 1,760 \\
\hline
\end{tabular}

a. Dependent Variable: ZAKAT

Berdasarkan tabel 5 di atas dapat terlihat bahwa nilai VIF dari variabel NPN dan BOPO sebesar 1,760 artinya < 10. Dan Telerance dari variabel NPM dan BOPO sebesar 1,760 artinya > o,1 jadi, dapat disimpulkan bahwa variabel NPM dan BOPO tidak terjadi gejala multikolinieritas.

\section{Uji Heteroskedastisitas}

Uji heteroskedastisitas adalah keadaan dimana dalam model regresi terjadi ketidaksamaan varian dari residual satu pengamatan ke pengamatan yang lain. Model regresi yang baik adalah tidak terjadi heteroskedasitisitas. Uji heteroskedastisitas dengan cara menggunakan uji glejser dengan cara meregesikan antara independen dengan nilai residualnya independen dengan absolut residual lebih dari 0,05 maka tidak terjadi masalah heteroskedastisitas. Hasil perhitungan uji Heteroskedastisitas dilihat pada tabel ini.

\section{Uji 6}

\section{Uji Heteroskedastisitas}

\section{Coefficients $^{\mathbf{a}}$}

\begin{tabular}{|l|c|c|c|c|c|}
\hline \multirow{3}{*}{ Model } & \multicolumn{2}{|c|}{$\begin{array}{c}\text { Unstandardized } \\
\text { Coefficients }\end{array}$} & $\begin{array}{c}\text { Standardized } \\
\text { Coefficients }\end{array}$ & \multirow{2}{*}{ T } & Sig. \\
\cline { 2 - 4 } & B & Std. Error & Beta & & \\
\hline
\end{tabular}

JISFIM: Journal of Islamic Social Finance Management, Volume 1, No 2 Tahun 2020 http://jurnal.iain-padangsidimpuan.ac.id/index.php/JISFIM 
185 I Pengaruh Net Profit Margin dan Rasio Biaya Operasional Pendapatan Operasional Terhadap Kemampuan Zakat

\begin{tabular}{|ll|r|r|r|r|r|}
\hline 1 & (Constant) & 3,040 &, 812 & & 3,741 &, 001 \\
& NPM &, 049 &, 014 &, 556 & 3,399 &, 002 \\
& BOPO &,- 015 &, 009 &,- 279 & $-1,706$ &, 100 \\
\hline
\end{tabular}

a. Dependent Variable: ZAKAT

Berdasarkan tabel 6 di atas dapat diliha nilai signifikansi NPM sebesar oo2 dan BOPO sebesar 100, artinya kedua variabel indenden > 0,05 dengan demikian dapat disimpulkan bahwa tidak terjadi masalah heteroskedastisitas pada model regresi.

\section{Uji Autokorelasi}

Uji Autokorelasi digunakan untuk mengetahui ada atau tidaknya penyimpangan asumsi klasik autokorelasi, yaitu korelasi yang terjadi antara residual pada satu pengamatan lain pada model regresi. Prasyarat yang harus terpenuhi adalah tidak adanya autokolerelasi dalam modal regresi. Ukuran dalam menentukan ada tidaknya masalah autokorelasi dengan uji DurbinWatso (uji D-W) dengan ketentuan nilai DW lebih besar dari -2 dan lebih kecil dari +2. Hasil perhitngan uji autokorelasi dilihat pada tabel di bawah ini:

\section{Uji IV 7}

\section{Uji Autokorelasi}

Model Summaryb

\begin{tabular}{|c|c|c|c|c|c|c|c|c|c|c|}
\hline \multirow[b]{2}{*}{$\begin{array}{l}\text { Mod } \\
\text { el }\end{array}$} & \multirow[b]{2}{*}{$\mathrm{R}$} & \multirow[b]{2}{*}{$\begin{array}{c}\mathrm{R} \\
\text { Squ } \\
\text { are }\end{array}$} & \multirow[b]{2}{*}{$\begin{array}{c}\text { Adjuste } \\
\text { d R } \\
\text { Square }\end{array}$} & \multirow{2}{*}{$\begin{array}{c}\text { Std. } \\
\text { Error } \\
\text { of the } \\
\text { Estima } \\
\text { te }\end{array}$} & \multicolumn{5}{|c|}{ Change Statistics } & \multirow[b]{2}{*}{$\begin{array}{l}\text { Durbin- } \\
\text { Watson }\end{array}$} \\
\hline & & & & & $\begin{array}{c}\text { Square } \\
\text { Chang } \\
\text { e }\end{array}$ & $\begin{array}{c}\text { F } \\
\text { Chan } \\
\text { ge }\end{array}$ & $\begin{array}{c}\mathrm{df} \\
1\end{array}$ & $\begin{array}{c}\mathrm{df} \\
2\end{array}$ & $\begin{array}{c}\text { Sig. F } \\
\text { Chan } \\
\text { ge }\end{array}$ & \\
\hline 1 & $\begin{array}{r}, 76 \\
8^{\text {a }}\end{array}$ & $\begin{array}{r}, 59 \\
0\end{array}$ & ,560 & 29384 & (590 & $\begin{array}{r}19,43 \\
4\end{array}$ & 2 & 27 & , 000 & 1,228 \\
\hline
\end{tabular}

a. Predictors: (Constant), BOPO, NPM

b. Dependent Variable: ZAKAT

Berdasarkan Tabel 7 di atas dapat dilihat dari Durbin- Watson sebesar 1,228 sehingga dapat dinyatakan tidak terjadi autokorelasi. Hal ini dikarenakan nilai Durbin-Watson lebih besar dari -2 dan lebih kecil +2, jadi dapat disimpulkan tidak terdapat hubungan antara periode yang terjadi antara variabel bebas (NPM dan BOPO) terhadap Zakat.

\section{Analisis regresi Linier Berganda}

Analisi regresi linier berganda digunakan untuk mengetahui pengaruh atau hubungan secara linier antara dua atau lebih variabel independen dengan satu variabel dependen. 
Penelitian ini akan menentukan bagaimana hubungan NPM, BOPO terhadap Zakat. Dalam hal ini peneliti mencari hubungan antara variabel-variabel tersebut.

Tabel 8

Uji Linier Berganda

Coefficients $^{\mathbf{a}}$

\begin{tabular}{|rl|r|r|r|r|r|}
\hline \multirow{2}{*}{ Model } & \multicolumn{2}{|c|}{$\begin{array}{c}\text { Unstandardized } \\
\text { Coefficients }\end{array}$} & $\begin{array}{c}\text { Standardized } \\
\text { Coefficients }\end{array}$ & & \\
\cline { 2 - 4 } & \multicolumn{1}{|c|}{ B } & Std. Error & Beta & \multicolumn{1}{c|}{$\mathrm{t}$} & \multicolumn{1}{c|}{ Sig. } \\
\hline 1 & (Constant) & 10,676 & 10,995 & &, 971 &, 340 \\
& NPM &,- 185 &, 095 &,- 310 & $-1,952$ &, 061 \\
& BOPO & 6,116 & 1,799 &, 539 & 3,399 &, 002 \\
\hline
\end{tabular}

a. Dependent Variable: ZAKAT

Berdasarkan hasil pengukuran regresi yang ditunjukkan pada tabel 8 di atas, maka persamaan regresi yang berbentuk adalah.

$$
\text { Zakat }=\alpha+\beta_{1} \mathrm{NPM}+\beta_{2} \mathrm{BOPO}
$$

Sehingga $Y^{\prime}=10,676-185$ NPM + 6,116 BOPO.

Berdasarkan persamaan regresi tersebut dapat diartikan jika NPM dan BOPO diasumsikan o maka zakat sebesar 6,116. Setiap peningkatan BOPO sebesar 1 satuan persen, maka akan meningkatkan zakat sebesar 6,116 satuan persen dengan asumsi variabel dependen lain nilainya tetap. Standar Error yaitu angka yang menunjukkan kemampuan moddl untuk memprediksikan variabel dependen, semakin kecil angka ini maka model regresi semakin tepat digunakan untuk memprediksi zakat.

\section{Koefisien Determinasi $\left(\mathbf{R}^{2}\right)$}

Koefisien determinasi $\left(\mathrm{R}^{2}\right)$ pada intinys mengukur seberapa jauh kemampuan model dalam menjelaskan variabel dependen bila nilai $\mathrm{R}^{2}$ Kecil berarti kemampuan variabel-variabel independen dalam menjelaskan variasi variabel dependen sangat terbatas. berikut hasil uji determinasi $\mathrm{R}^{2}$ kecil berarti kemampuan variabel-variabel independen dalam menjelaskan variasi variabel dependen sangat terbatas, berikut hasil uji determinasi $\mathrm{R}^{2}$ dapat dilihat sebagai berikut.

Tabel 9

\section{Uji Koefisien Determinasi}

JISFIM: Journal of Islamic Social Finance Management, Volume 1, No 2 Tahun 2020 http://jurnal.iain-padangsidimpuan.ac.id/index.php/JISFIM 
Model Summary

\begin{tabular}{|l|r|r|r|r|}
\hline Model & R & R Square & \multicolumn{1}{c|}{$\begin{array}{c}\text { Adjusted R } \\
\text { Square }\end{array}$} & Std. Error of the Estimate \\
\hline 1 &, $768^{\mathrm{a}}$ &, 590 &, 560 &, 29384 \\
\hline
\end{tabular}

a. Predictors: (Constant), BOPO, NPM

b. Dependent Variable: ZAKAT

Hasil interprestasi dari R o,768 artinya korelasi antara variabel NPM dan BOPO terhadap Variabel Zakat sebesar 0,768. Hal ini menunjukkan bahwa terjadi hubungan yang kuat antara BOPO dan NPM terhadap Zakat. Hasil Koefisien determinasi $\left(\mathrm{R}^{2}\right)$ sebesar 0,590. Hal ini menunjukkan bahwa BOPO dan NPM mampu menjelaskan variansi Variabel Zakat sebesar 59,0 \% sedangkan sisanya sebesar 41 \% dijelaskan oleh faktor atau variabel lain di luar variabel yang diteliti yaitu bagi hasil dan tenaga hasil.

\section{Uji Signifikan Parsial (Uji-t)}

Untuk mengetahui apakah koefisien regresi sigtifikan atau tidak, maka digunakan uji t untuk menguji signifikasi konstanta dan variabel dengan cara sebagi berikut:

\section{Tabel 10}

\section{Hasil Uji Persial (Uji-t)}

Coefficients ${ }^{\mathbf{a}}$

\begin{tabular}{|c|c|c|c|c|c|c|}
\hline \multirow{2}{*}{\multicolumn{2}{|c|}{ Model }} & \multicolumn{2}{|c|}{$\begin{array}{c}\text { Unstandardized } \\
\text { Coefficients }\end{array}$} & \multirow{2}{*}{$\begin{array}{c}\text { Standardized } \\
\text { Coefficients }\end{array}$} & \multirow[b]{2}{*}{$\mathrm{T}$} & \multirow[b]{2}{*}{ Sig. } \\
\hline & & $\bar{B}$ & Std. Error & & & \\
\hline \multirow[t]{3}{*}{1} & (Constant) & 3,040 & ,812 & & 3,741 & ,001 \\
\hline & NPM & ,049 & ,014 &, 556 & 3,399 & ,002 \\
\hline & BOPO &,- 015 & ,009 &,- 279 & $-1,706$ & ,100 \\
\hline
\end{tabular}

a. Dependent Variable: ZAKAT

Berdasarkan Tabel 10 di atas dapat dilihat bahwa variabel NPM memiliki $t_{\text {hitung }}$ sebesar 2,406 dengan nilia signifikan 0,002<0,05 maka $\mathrm{H}_{\mathrm{a}}$ diterima Berarti secara parsial terdapat pengaruh signifikan NPM terhadap zakat. hal ini disebabkan BOPO juga dipengaruhi total aset yang dimiliki mempuyai pengaruh yang besar dalam memoderasi pengaruh NPM terhadap zakat. Sedangkan untuk variabel BOPO nilai $t_{\text {hitung }}$ sebesar 1,706 dan $t_{\text {tabel }}$ sebesar 2,03452 sehingga $t_{\text {hitung }}>t_{\text {tabel }}(1,706<2,03452)$ maka $\mathrm{H}_{\mathrm{o}}$ ditolak dan $\mathrm{H}_{\mathrm{a}}$ diterima. Sehingga dapat ditarik kesimpulan bahwa secara parsial tidak terhadap pengaruh BOPO terhadap zakat. Hal ini disebabkan jika NPM tinggi akan berdampak pada pendapatan laba yang meningkat sehingga 
kemampuan zakat akan bertambah. Sebaliknya jika BOPO rendah akan berpengaruh terhadap kemampuan zakat yang semakin menurun.

\section{Uji Simultan (Uji F)}

Uji F pada dasarnya menunjukkan apakah semua variabel bebas yang dimaksudkan dalam model mempunyai pengaruh secara bersama-sama terhadap variabel terikat/dependen.

\section{Tabel Uji 11}

Uji F

ANOVAa

\begin{tabular}{|c|c|c|c|c|c|c|}
\hline \multicolumn{2}{|c|}{ Model } & $\begin{array}{l}\text { Sum of } \\
\text { Squares }\end{array}$ & $\mathrm{df}$ & $\begin{array}{c}\text { Mean } \\
\text { Square }\end{array}$ & $\mathrm{F}$ & Sig. \\
\hline \multirow[t]{3}{*}{1} & Regression & 3,356 & 2 & 1,678 & 19,434 &, $000^{b}$ \\
\hline & Residual & 2,331 & 27 & ,086 & & \\
\hline & Total & 5,687 & 29 & & & \\
\hline
\end{tabular}

a. Dependent Variable: ZAKAT

b. Predictors: (Constant), BOPO, NPM

Berdasarkan Tabel 11 di atas dapat dilihat bahwa nilai $F_{\text {hitung }}$ sebesar 19,434 dan $F_{\text {tabel }}$ sebesar 3,28 sehingga $F_{\text {hitung }}$ lebih besar dari $F_{\text {tabel }}(19,434>3,28)$. Sehingga dapat diperoleh kesimpulan bahwa NPM dan BOPO secara simultan berpengaruh terhadap zakat. Artinya perkembangan dari variabel zakat (Y) dapat dipengaruhi oleh kedua variabel bebas yaitu NPM (X1) dan BOPO (X2).

\section{Pembahasan Hasil Penelitian}

\section{Pengaruh Net Profit Margin (NPM) terhadap Zakat pada PT. Bank Syariah}

\section{Mandiri tahun 2004 - 2018.}

Berdasarkan hasil penelitian yang dilakukan dengan menggunakan program SPSS versi 22, maka diperoleh hasil thitung variabel NPM sebesar 2,406 dengan nilai signifikan 0,002<0,05 maka $\mathrm{H}_{\mathrm{a}}$ diterima. Berarti secara persial terdapat pengaruh signifikan NPM terhadap zakat. NPM tidak dapat digunakan untuk memprediksi zakat karena di uji secara parsial menunjukkan tidak ada pengaruh signifikan antara variabel X1 (NPM) terhadap variabel Y (zakat).

\section{Pengaruh rasio Biaya Operasinal Pendapatan Operasional (BOPO) terhadap Zakat} pada PT. Bank Syariah Mandiri tahun 2004 - 2018.

Hasil penelitian ini diperoleh hasil nilai $t_{\text {hitung }}$ lebih besar 1,706 dan $t_{\text {tabel }}$ sebesar 2,03452 sehingga $t_{\text {hitung }}$ lebih besar dari $t_{\text {tabel }}(1,706>2,03452)$. Dengan nilai signifikan $0,100>0,05$ maka $\mathrm{H}_{\mathrm{o}}$ ditolak. Sehingga dapat ditarik kesimpulan bahwa secara persial tidak terdapat pengaruh JISFIM: Journal of Islamic Social Finance Management, Volume 1, No 2 Tahun 2020 http://jurnal.iain-padangsidimpuan.ac.id/index.php/JISFIM 
BOPO terhadap zakat. Berdasarkan hasil yang diperoleh pseneliti dimana BOPO (X2) secara parsial tidak memiliki pengaruh signifikan terhadap zakat.

\section{Pengaruh Net Profit Margin (NPM) dan rasio Biaya Operasional Pendapatan Operasional terhadap Zakat PT. Bank Syariah Mandiri 2004-2018.}

Berdasarkan hasil penelitian yang dilakukan dengan menggunakan program SPSS versi 22, jika variabel independen di uji secara simultan terhadap variabel dependen maka diperoleh hasil nilai $F_{\text {hitung }}$ sebesar 19,434 dan $F_{\text {tabel }}$ sebesar 3,28 sehingga $F_{\text {hitung }}$ lebih besar dari $F_{\text {tabel }}$ $(19,434>3,28)$ sehingga dapat diperoleh kesimpulan bahwa NPM dan BOPO secara simultan berpengaruh terhadap zakat, artinya perkrmbangan dari variabel Zakat (Y) dapat dipengaruhi oleh kedua variabel yaitu NPM (X1) dan BOPO (X2).

\section{KESIMPULAN}

Berdasarkan rumusan masalah yang telah dikemukakan dapat disimpulkan berdasarkan uji Parsial (uji t) pada NPM dengan nyata 5\% diperoleh nilai signifikan 0,002>0,05 maka $\mathrm{H}_{\mathrm{a}}$ ditolak. Berarti secara parsial terdapat pengaruh signifikan NPM terhadapt zakat. Hal ini disebabkan NPM juga dipengaruhi total aset, sementara total aset pada BSM tidak selalu tetap. Sehingga total aset yang dimiliki mempunyai penagruh yang besar dalam memoderasi pengaruh NPM terhadap Zakat. Berdasarkan Uji parsial (uji t) pada variabel BOPO diperoleh nilai signifikan 0,100<0,05 maka Ho diterima dan Ha ditolak. Sehingga dapat ditarik kesimpulan bahwa secara persial BOPO berpengaruh signifikan terhadap zakat. Berdasarkan uji F dengan taraf nyata 5\% maka diperoleh nilai Fhitung sebesar 19,434 dan Ftabel sebesar 3,28 sehingga Fhitung lebih besar dari Ftabel $(19,434>3,28)$ sehingga dapat diperoleh kesimpulan bahwa NPM dan BOPO secara simultan berpegaruh terhadap zakat. Artinya perkembangan dari variabel Zakat (Y) dapat dipengaruhi olehnkedua variabel bebas yaitu NPM (X1) dan BOPO (X2). Berdasarkan hasil kesimpulan diatas penelitian dapat memberikan saran yaitu bagi Bank Syariah yang sudah mampu (nisab) untuk menunaikan zakat dan perlu mempublikasikan laporan keuangan agar masyarakat mengetahui bahwa perbankan syariah sudah menunaikan zakat sesuai dengan prinsip syariah. Untuk meningkatkan pertumbuhan zakat maka dibutuhkan skala operasi yang cukup besar, walaupun hanya berpengaruh sedikit kinerja angka pembayaran zakat yang tinggi maka terlebih dahulu meningkatkan kinerja keuangan secara menyeluruh. Bagi peneliti berikutnya diharapkan menambah rasio keuangan lainnya sebagai variabel independen, karean sangat dimungkinkan rasio keuangan lain yang tidak dimasukkan dalam 
penelitian ini berpengaruh terhadap kemampuan zakat. Kepada pembaca diharapkan setelah membaca skripsi ini dapat memberikan kritik dan aran kesempurnaan skripsi ini. Serta dapat menjadi rujukan dalam penelitian selanjutnya.

\section{DAFTAR PUSTAKA}

Abu Hamid Muhammad Al-Ghazali, Rahasia Puasa dan Zakat, diterjermahkan dari "Asrar Ash-Ash-Shaum dan Asrar Az-Zakat” oleh Muhammad Bagir ,Bandung : Karisma, 1993, hlm. 55 .

Duwi Priyatno, Cara Mandiri belajar SPSS , Yogyakarta: Mediakom, 2012, hlm. 38.

Dwi Priyanto, SPSS 22 Pengolahan Data Terpraktis ,Yogyakarta: CV Andi Offset, 2014, hlm.91.

Departemen Agama RI, AL-Qur'an dan Terjemahnya , Bandung Syaamil Quran, 2009, hlm. 595 .

Didin Hafidhuddin, Jakat Dalam Perekonomian Modren, Jakarta: Gema Insani, 2002, hlm. 33.

Freddy Rangkuti, Analisis SWOT: Teknik Membeda Kasus Bisnis Cara Perhitungan Bobot, Rating, dan OCAI ,Jakarta: PT. Gramedia, 2016, hlm. 123.

Frianto Pandai, Manajemen Dana dan Kesehatan Bank, Jakarta : Rineka Cipta 2012

Hery, Analisis Laporan Keuangan ,Jakarta: PT Bumi Aksara, 2014, hlm. 22.

Harahap, Sofyan, Menejemen Perumusan Teori Akutansi Islam, Jakarta PT. Pustaka Quantum, 2001.

Iqbal Hasan, Pokok-pokok Statistic 2 , Statistik Inferensif, Jakarta: Bumi Aksara, 2008, hlm.84. Iwan Triyuwono, Akuntansi Syariah: Perpekstif Metodologi, dan Teori, Jakarta: Rajawali Pers, 2012,hlm.213.

Jumingan, Analisis Laporan Keuanagan, Jakarta : PT. Bumi Aksara, 2011, hlm. 245.

Kasmir, Analisis Laporan Keuangan, Jakarta: PT Raja Grafindo Persada, 2002

K. Fred Skousen, dkk., Akuntansi Keuangan, Jakarta: Salemba Empat, 2001.

Lukman Dendawijaya, Manajemen Perbankan, Jakarta: Ghalia Indonesia, 2009.

M, Ali Hasan, zakat dan Infak Salah Satu Mengatasi Problema Sosial di Indonesia, Jakarta: 2006.

Munawir, Analisis Laporan Keuangan, Yogyakarta: Liberty, 2007, hlm. 1

Murasa Sarkaniputra, Adil dan Ihsan dalam Perpekstif Ekonomi Islam ,Jakarta: Pusat Pengkajian dan Pengembangan Ekonomi Islam,2005,hlm.6o

JISFIM: Journal of Islamic Social Finance Management, Volume 1, No 2 Tahun 2020 http://jurnal.iain-padangsidimpuan.ac.id/index.php/JISFIM 
Mudrajad Kuncoro, Metode Riset untuk Bisnis dan Ekonomi , Jakarta: Erlangga, 2013

Mudrajad Kuncoro, Metode Riset untuk Bisnis dan Ekonomi , Jakarta: Erlangga, 2013.

Nuruddin Mhd, Zakat Sebagai Instrumen Dalam Kebijakam Fiskal Jakarta: Pt. Raja Grafindo Persada, 2006,hlm.6.

Rosady Ruslan, Metode Penelitian, Jakarta : PT.Raja Grafindo Persada, 2004, hlm.7.

Pengantar Akuntansi Syariah, Jakarta: Salemba Empat, 2002, hlm.141.

Sofyan Syafri Harahap, Menuju Perumusan Teori Akuntansi Islam, Jakarta : PT. Pustaka Quantum, 2001, hlm.305

Syofyan Syafri Hararap, Menuju Perumusan Teori Akuntansi Islam, Jakarta: Pustakan Quatum, 2001, hlm. 298.

Sri Nurhayati dan Wsilah, Akuntansi Syariah di Indonesia ,Jakarta: Salem Empat, 2013, hlm. 295.

Sugiono, Metode Penelitian Bisnis ,Bandung: Alfabeta, 2013.

Suharsimi Arikunto, Prosedur Penelitian Suatu Pendekatan Praktik ,Jakarta: Rineka Cipta, 2006, hlm 67.

Sumardi Suryabrata, Metologi Penelirian, Jakarta : PT. Raja Grafindo Persada, 2012.

Suryani dan Hendryadi, Metode Riset Kuantitatif, Jakarta: Kencana, 2016

Sutan Remy Sjahdena, Perbankan Syariah, Jakarta: Kencana, 2016

Syaifuddin Azwar, Metode penelitian, Yogyakarta: Pustaka Pelajar, 2004,, hlm.5

Undang -undang No. 38 Tahun 1999 Tentang Zakat.

Umrotul Khasanah, Manajemen Zakat Modern , Malamg: UIN-MALIKI PESS,2010,hlm.37.

Veithzal Rivai dan Andria Permata Veithzal, Islamic Financial Management, Jakarta: Rajawali Perts, 2012, hlm 213.

Veithzal Rivai, dkk., Bank and Financial Institution Management Conventional \& Sharia System, Jakarta : PT. Raja Grafindo Persada, 2007, hlm. 722.

Wahbah Al-Islami Adilstuh, Zakat: Kajian Berbagai Mazhab (Bandung: PT Remaja Rosdakarya, 2000), hlm. 82.

Zainal Arif, Dasar-dasar Manajemen Bank Syariah ,Jakarta: Pustaka alvabet, 2006, hlm. 95. 